\section{The Belo Horizonte Observatory for Urban Health: its history and current challenges}

\author{
O Observatório de Saúde Urbana de Belo \\ Horizonte: sua história e desafios atuais \\ El Observatorio de Salud Urbana de Belo \\ Horizonte: su historia y retos actuales
}

\author{
1 Faculdade de Medicina, \\ Universidade Fedderal de \\ Minas Gerais, Belo Horizonte, \\ Brasil. \\ 2 Observatório de Saúde \\ Urbana de Belo Horizonte, \\ Belo Horizonte, Brasil. \\ Correspondence \\ M. A. S. Dias \\ Av. Álvares Cabral 917, apto. \\ 502, Belo Horizonte, $M G$ \\ 30130-001, Brasil. \\ angelica@pbh.gov.br
}

\begin{abstract}
The Belo Horizonte Observatory for Urban Health (OSUBH), housed in an academic setting, was founded in 2002 as part of a broader agenda to strengthen local and national health systems. Its mission is to build the capacity of the workforce in research on population health and to conduct studies on urban issues that can guide the planning of activities aimed at improving the health of populations, especially in heavily urbanized areas, associated with intraurban inequalities. It focuses on the acquisition of advanced knowledge on urban health (metric) through scientific research, to contribute to public policies that may interfere with health, both at individual and community levels. During its lifetime, many partnerships and studies have been developed, but many challenges still exist in order for it to consolidate its position as a legitimate space and as a tool to generate sys tematic information for governments and populations.
\end{abstract}

Health Planning; Health Research Agenda; Urban Health
Maria Angelica de Salles Dias 1,2 Amélia Augusta de Lima Friche 1,2 Veneza Berenice de Oliveira 1,2 Waleska Teixeira Caiaffa 1,2

\section{Resumo}

O Observatório de Saúde Urbana de Belo Horizonte (OSUBH), aninhado em um ambiente acadêmico, foi fundado em 2002, em uma intensa agenda de saúde local e nacional. Sua missão é construir a capacidade da força de trabalho em pesquisa em saúde da população e realizar estudos urbanos com temas que podem orientar o planejamento de ações para melhorar a saúde das populações, especialmente em áreas intensamente urbanizadas, associadas com desigualdades intraurbanas. Centra-se na aquisição de conhecimentos aprofundados sobre a saúde urbana (métricas) por meio de pesquisa científica, visando a contribuir com políticas públicas que possam interferir na saúde, tanto no nível individual como no comunitário. Em sua trajetória, parcerias e estudos têm sido implementados, mas muitos desafios se colocam para a sua legitimação no sentido de consolidar-se como ferramenta na geração de informações sistemáticas para governos e população.

Planejamento em Saúde; Agenda de Pesquisa em Saúde; Saúde Urbana 


\section{Background and context for urban health observatories}

The Belo Horizonte Observatory for Urban Health (OSUBH, in Portuguese) was established through a process led by the local university and health services to bring together academics and public sector services. This partnership was initiated in the mid-1990s between the Belo Horizonte Health Department (SMS-BH, in Portuguese) and the School of Medicine at the Federal University of Minas Gerais (UFMG). The partnership was mediated by municipal technicians in the SMS-BH and academics associated with the Epidemiology Research Group at UFMG, registered with the Brazilian National Research Council (GPE-CNPq).

The combination of researchers and municipal technicians seeking advanced public health training and qualifications created meaningful exchanges, providing the foundation for the establishment of the OSUBH at UFMG in 2002. The team was equipped with strong epidemiological and public health training, and was driven by a common interest in finding ways of bridging the gap between the science and practice of public health. Particular attention was paid to the complex determinants of health in the context of increasing urbanization, and the relationships between the different facets of urban life and health inequities, which called for integrated strategies to solve public health problems 1 .

\section{Brief review of the international context}

On the international scene, despite great advancements being made in the understanding of "health promotion" as an integral part of health care in the 1970s and 1980s shaped by the Lalonde Report (1974), the Alma Ata Declaration (1978), the Ottawa Letter (1986) and other international events that followed, a primarily curative approach to people's health dominated worldwide in the 1990s to the detriment of more holistic models of health 1 . Political and economic obstacles hampered a more global approach to health and the social determinants of health in those days.

However, towards the start of the new century, which saw new global changes - political, epidemiological, demographic and climatic - a vigorous reformulation of public policy regarding health promotion was observed in several countries marked by a systematic approach to the social determinants of health 1,2 . After the creation of the Commission on Social Determinants of Health $(\mathrm{CSDH})$ by the World Health Organization (WHO) in 2005, the social determinants of health approach contributed to enrich global discussions on the social, political, economic, cultural, behavioral and individual determinants of health, and how they influenced health disparities. This approach advanced strategies to address health inequities, including inter-sectoral "health promotion" 2 policies, underlying the understanding that health promotion goes beyond the matter of health - it is a matter of life and social justice.

In this international process of theoretical and political reconstruction of health, Brazil took a firm position with the creation of the National Committee of Social Determinants of Health (CNDSS) and the approval of the National Policy of Health Promotion in 2006. Furthermore, through the Healthy Cities Program launched by WHO in 1994 and led in the Americas by the Pan American Health Organization (PAHO), a Brazilian network of Healthy Cities was created 3,4,5.

Brief review of the local and national context

From the outset, the academic-public service partnership established by the OSUBH was focused on the state capital of Belo Horizonte, a prominent reference city for both the metropolitan region as well as for the state of Minas Gerais. Initially a planned city, its population grew by $55 \%$ during the 1940s, disrupting the initial urban organization. By the year 2010, with 2,375,444 inhabitants, Belo Horizonte ranked as the $6^{\text {th }}$ most populous Brazilian capital.

In the context of ever-increasing urbanization, Belo Horizonte has faced multiple challenges like any other large urban center - waste accumulation, air pollution, traffic management, insufficient housing, and complex social dynamics. These have led to unfavorable living conditions and increased social problems with significant health implications. Associated with these conditions is the magnitude of the sprawling city peripheries with large clusters of urban slums characterized by social deprivation, greater vulnerability to disease and death, and the lack of access to goods and services, further deepening health inequities in the region 6 .

From a scientific viewpoint, the OSUBH boldly sought to go beyond individual risk factors and the traditional model of health, disease, and the environment, to encompass the broader determinants of health and ill health. The acknowledgement of the city as a place where space and social relations intertwine with socio-political, cultural and economic factors to influence people's health was instrumental in reshaping the field of urban health 7,8 . 
From the city's viewpoint, the health department and the city hall of Belo Horizonte, with a democratically elected popular government from the end of the 1990s to the early 2000s, constructed the foundation of a health system prioritizing primary healthcare and comprehensive and fair healthcare. When organizing its health services focusing on comprehensive care, Belo Horizonte highlighted health promotion and the interconnection of various public policies for mitigating disease processes 9 .

In this context, the city was also building a system of public policy-making through participatory budgeting 10 . The aim was to create an administration which achieves three aims: to consider the urbanization of slums as a means of joining the informal to the formal city; to develop projects with intersectoral action plans for vulnerable groups, families and territories; and to advance health indicators, including the use of geographic information systems, to generate intra-urban indicators which are fundamental to understanding health and its determinants within a city 9 .

Beyond Belo Horizonte city boundaries, in the broader context of Brazilian politics, the health reform movement was consolidating throughout the 1980s. It culminated in an intense mobilization at the VIII National Health Conference in 1986, which laid the groundwork for the public and universal Brazilian Unified National Health System (SUS). With comprehensiveness and fairness as guiding principles, SUS marked an important moment in Brazilian public health 11,12.

Breaking away from the individualized perspective of disease and death, and widening the focus to go beyond the limits of the health sector, this national movement redefined health as " $a$ result of nutrition, housing, education, income, environment, employment, transport, career, leisure, liberty, land access and ownership, and access to health services. Therefore health is, primarily, a result of the forms of social organization of production, which can cause inequities in living standards" 11. This concept, later integrated into the Federal Constitution of 1988 (Article 196, Section II-Health), established the foundation for connecting health promotion and the current understanding of the social determinants of health 9,13.

\section{Urban health and the OSUBH}

The explosive and disorderly growth of cities, even of those initially established as planned, and the adverse consequences for the health and equity situation of the urban population, triggered both national and international attention 14 . It also gave momentum to initiatives headed by international organizations such as WHO and PAHO as well as international professional societies to promote further research and action to address the social determinants of health in urban settings.

A major landmark was the 1st International Conference on Inner City Health: Improving the Health of the Disadvantaged, held in Canada in October 2002. It was reconvened for a second time, one year later, under a new name, the International Conference on Urban Health (ICUH). From that point forward, ICUH has provided a platform for advancing urban health theory, research methods, and practice, as an emerging field of public health.

Against this background, there were several additional key events that propelled the field of urban health forward:

- The creation, in 1995, of the WHO Centre for Health Development (WHO Kobe Centre) in Japan and its focus on urbanization as a key driver of health development 14;

- The establishment of the International Society for Urban Health (ISUH), based at the New York Academy of Medicine and the publication of the Journal of Urban Health;

- The reports from the WHO CSDH, with specific recommendations for action on the social determinants of health and urban health 15,16,17;

- The PAHO forums on urban health in Mexico (2007) and New York, USA (2010), focusing on concepts and metrics 18;

- The urban health strategy and action plan of the 51st PAHO Directing Council in 2011 in Washington DC (USA), which included recommendations for strengthening ties between government and academic institutions, promoting action by collaborating centers, funding relevant research (as identified by observatories), promoting practices that address the impact of urbanization on health and the social gradient in health, and capacity building in urban health (including through developing human and financial resources for the establishment and negotiation of integrated urban health policies and interventions) 19 and;

- The World Conference on Social Determinants of Health held in Brazil in 2011, which urged Member States to monitor progress and increase accountability in addressing the social determinants and their impact on health and health equity 20 .

In 2004 the IV Conference on Epidemiology, held in Brazil, addressed the theme 'Looking Out Over the City' and in 2005 the Cadernos de Saúde Pública published the first forum on urban health 21 . In 2008, Caiaffa et al. 7 proposed a Brazilian theoretical model of social determinants 
and urban health, adapted from the WHO. All of these initiatives contributed to the consolidation of the field of urban health, defined as a branch of public health that studies the opportunities and risks of the cities, and their effects on health and social relations 8 .

These initiatives provided recommendations for governments to take comprehensive action to reduce inequities and improve health in urban settings. Moreover, the creation and expansion of urban health observatories was recommended as a way of closely examining health in large cities and the negative consequences of uncontrolled growth without consideration of social relations 20 . This resulted in several initiatives to create urban health observatories in Brazil and around the world 22,23.

The OSUBH has been tracking these advancements and substantially increasing the theoretical and practical knowledge on the new health promotion agenda 22 with a strong academic emphasis, unlike other observatories established by non-governmental organizations or government, which might have a different focus. The academic locus of the OSUBH has provided political autonomy for the observatory, though not without challenges.

\section{OSUBH activities}

Throughout its 12 years of existence, OSUBH has been a space for reflection and elaboration of urban health themes, focusing on intra-urban health inequities 21,22 . Driven by a conceptual framework of urban health based on the social determinants of health approach 7,17, OSUBH started with ecological investigations using data on health outcomes and intra-urban indices, constructed either by the city health or city planning unit of Belo Horizonte, in addition to census data. Besides health promotion as a major thematic axis, other aims of the OSUBH included: monitoring spatial and temporal trends in health events; identifying areas with a lack of, or need for, health-related information; using and constructing indicators for evaluating health interventions and their impact on inequities; and designing and conducting research projects to assess and evaluate health services 22 . Initially established for advancing studies in the setting of Belo Horizonte city using an intersectoral approach, it has broadened its scope over the years to include a new research agenda in other urban settings through various partnerships.

The mission of OSUBH is knowledge acquisition through scientific research, at both individual and community levels, in order to build knowledge and workforce capacity in population health research and to conduct urban-themed studies that can drive planning for improving urban health. The main focus is to understand the social and environmental conditions of urban life through an intersectoral, multidisciplinary approach in order to provide empirical evidence for determining which urban health interventions can be applied in specific contexts (Figure 1).

To accomplish this task, contemporary methodological approaches have been implemented, such as multilevel analysis, in order to better understand how the urban space influences the health of citizens, and vice versa 22,24 . Such research also helps to comprehend how macro sociopolitical, economic and cultural conditions, public services supply and demand, and viability of governments influence the territorial organization of city dwellers.

\section{Training activities, projects and partnerships}

In addition to the academic role of educating and training undergraduate, master and PhD students through the UFMG Graduate Program in Public Health, the OSUBH offers courses in urban health, contributing to capacity building of students and professionals in various fields, including health, architecture, engineering, law, psychology, speech therapy, statistics, nutrition, and physical education, among others.

As for research projects, the OSUBH aims to develop urban health evaluation models to assist government agencies in their elaboration of public policies, in health and beyond, which positively impact inhabitants' health and quality of life. Figure 2 shows the current studies developed by the OSUBH team, including innovative projects on urban health and their different levels of attributes from individual to the governmental level. It is worthwhile to point out that these studies, directly or indirectly originating from the health sector, address the urban environment and its effects on health, including physical activity and the built environment, vector-related diseases environment, drug-use network, transport and mobility, and evaluation of interventions on urban regeneration in slums and other vulnerable areas of the city.

Regarding the evaluation project of urban slum regeneration, recently the OSUBH incorporated a health impact evaluation of urban interventions that are not necessarily originating from the health sector but have a potential impact on the health of dwellers. This is in accordance with the WHO statement that housing characteristics, including the interlinked dimensions of household, dwelling, community and neighborhood 
Figure 1

Urban health framework and the Belo Horizonte Observatory for Urban Health (OSUBH).
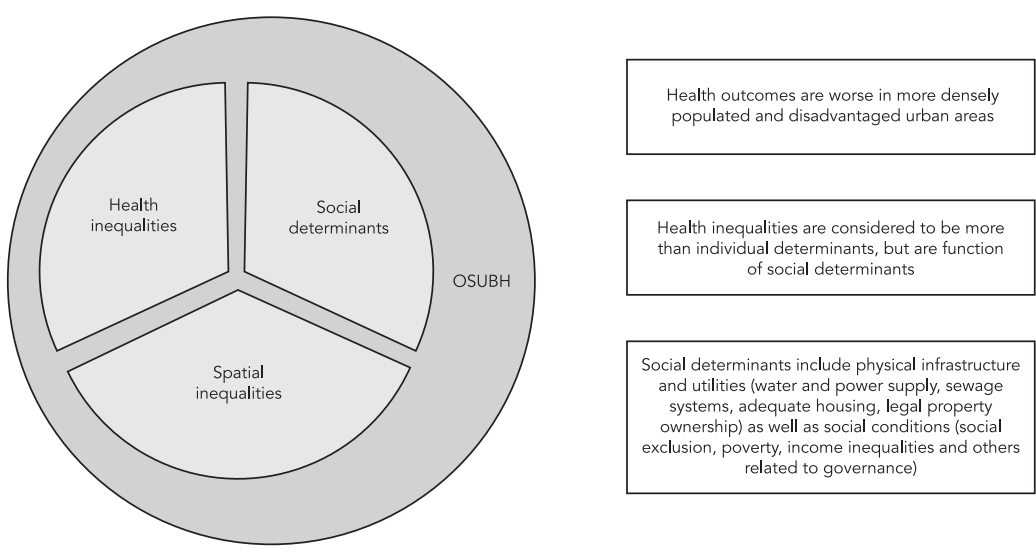

Health inequalities are considered to be more than individual determinants, but are function of social determinants

Social determinants include physical infrastructure and utilities (water and power supply, sewage systems, adequate housing, legal property
ownership) exclusion, poverty, income inequalities and others related to governance)

Combine efforts to provide an empirical basisfor determining which urban health interventions might work

Figure 2

Belo Horizonte Observatory for Urban Health (OSUBH) project-based studies.

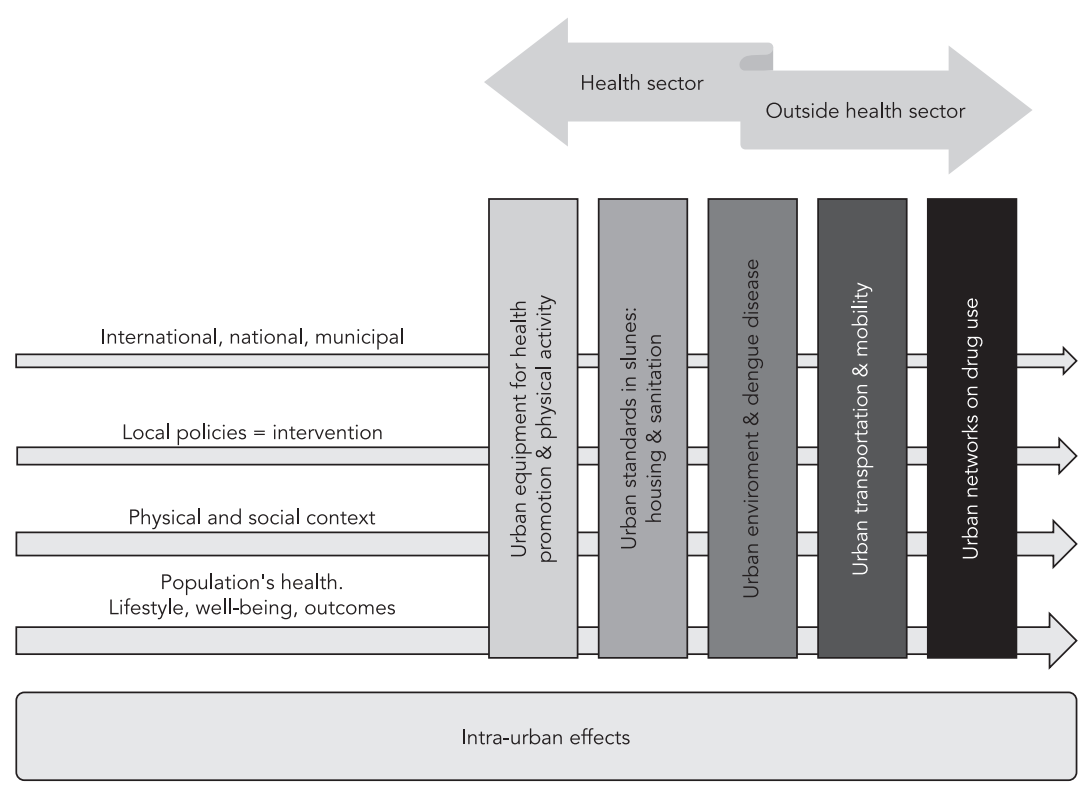


environment, have the capacity to affect individual health status through physical, mental or social mechanisms 25 .

In terms of national partnerships, the OSUBH is a collaborative center of the Health Surveillance Secretariat of the Brazilian Ministry of Health and has recent projects sponsored by the Executive Secretary and Health Care Department, CNPq and the Minas Gerais State Research Foundation (FAPEMIG). Also noteworthy is the Observatory's participation in the Healthy City Network forums coordinated by several universities, PAHO and the Brazilian Ministry of Health, in which new urban health evaluation models and experiences have been discussed. Locally, the OSUBH compiled two editions of the report on the Millennium Development Goals (MDG) in partnership with the Belo Horizonte municipality. Also, as a result of the intensity of training and research activities at the OSUBH, it recently initiated a partnership with the Oswaldo Cruz Foundation (Fiocruz) in order to build a Belo Horizonte-Rio de Janeiro Observatory.

Among the international partners of the $\mathrm{Ob}$ servatory, the following stand out: the University of Michigan, through its Center of Social Epidemiology and Population Health, with collaborative research projects and the training of doctorates and post-doctorates through the CNPq-Science Without Borders Program; the WHO Centre for Health Development in Kobe, Japan, and PAHO with joint efforts that have led to the publication of technical reports based on studies of urban health and health observatories; and the New York Academy of Medicine through participation in the board of the ISUH and also through studies on the experience of Belo Horizonte with participatory governance and participative democracy. In addition, in 2011, the OSUBH chaired the $10^{\text {th }}$ ICUH in Belo Horizonte, which allowed for the exchange of experiences between a wide network of national and international researchers and practitioners.

The impact of training activities, research project development, and national and international partnerships can be seen in the increased production of knowledge through the publication of peer-reviewed journal articles as well as several presentations to wide audiences of partners, technicians and researchers, nationally and internationally.

\section{Opportunities and challenges}

Based on our 12 years of experience, the establishment of a local urban health observatory may contribute as an institutional solution for the city to make data more accurate, qualified and meaningful through the compilation of diverse local sources, systematizing, analyzing and interpreting the data. However, despite the opportunities, challenges must also be acknowledged taking into consideration the complexity of the approach - in other words, the difficulty in answering the question, "What are some of the specific ways in which urban health studies can transform research into action?"

The first aspect of this has to do with the adequacy of a conceptual framework for producing information for action. Concerted efforts to obtain reliable primary or secondary data must be based on established conceptual models of heath in cities, focusing on specific domains to be studied. The aim should be to ensure that the advantages outnumber the challenges of city life by having intelligible and reliable information that can be used to elaborate public policies. The observatory should be guided by a clear conceptual framework leading towards its ultimate goal of paving the way that guarantees the health and well-being of citizens, and to equip the administration and other local actors with the knowledge necessary to face the, almost always uncontrolled, rapid rate of urban population growth.

The second dimension is the requirement for novel conceptualizations and methodological tools to capture the dynamics and complexities of cities, with multidirectional causality, feedback loops, and unintended consequences of interventions. Therefore, a search for new methodological approaches, such as complex systems analysis, may be one driver of development of health observatories.

A third issue, which poses a major challenge for OSUBH as it does for most existing observatories, is establishing legitimacy and sustainability. For this, the following are essential: (1) partnership maintenance and expansion (with governments, academics from distinct areas, international organizations and civil society); (2) intense capacity building in order to qualify professionals; (3) systematization of the collection and organization of data from diverse sources for predicting the occurrence of health events, and performing evaluations of possible scenarios to develop policy recommendations; (4) knowledge production in academia and research, aiming to build models for evaluating the determinants of health and disease, and the impacts of policies and services on urban health, resulting in plausible evidence that can contribute to adherence and confidence of stakeholders.

The search for financial sustainability, which provides the basis for maintaining the fundamental objective of the Observatory to contin- 
ue the production of knowledge for action, still needs advancing. It is also essential to transform partnerships into networks that foster sustainability. A concrete example is the partnership between the Fiocruz and the OSUBH in developing a joint study, and possibly, an outline for a network of observatories.

The fourth issue which presents both an opportunity and a challenge is the systematic production of information and its institutionalization so that the information will actually be utilized by governments to elaborate public policies to reduce inequities and promote health, quality of life and social justice. In this sense, the ongoing project for evaluating the health impacts of urban interventions in slums can become a model for the evaluation of integrated policies and the means to a new vision (Figure 2, last bar). This project is seen as an opportunity to gauge a comprehensive local intervention Projeto Vila-Viva, in Portuguese - in the slums of the city undertaking renovation projects involving urban and social policies through local partnership with the health and urban departments of Belo Horizonte. It is worth highlighting that such a model of intervention has now been a national priority policy in several Brazilian cities as part of the Brazilian Growth Acceleration Program (Programa de Aceleração do Crescimento, in Portuguese). Therefore, the opportunity in evaluating locally a national intervention model represents an enormous methodological challenge for OSUBH's team.

In this way other ongoing studies through partnerships with the Brazilian Ministry of Health comprising the evaluation of priority projects represent an opportunity as well as challenges 5 . They are: the built environment intervention for physical activity (Projeto Academias da Saúde) and the Road Traffic Crashes morbidity and mortality reduction program (Projeto Vida no Trânsito), in Figure 2

The final challenge is related to publicizing the knowledge produced, especially among the target populations, by creating strategic and appropriate mechanisms so that all can understand health, equity and their determinants in urban settings with its various dimensions.

In conclusion, most projects are resource intensive, and require methodological compromises and multiple stakeholder engagement. They are also faced with the challenge of studying a changing environment over which the researcher usually has limited or no control. Despite such challenges, the OSUBH has been optimistically treading its way through observing and analyzing the city and health through a broad 'social determinants of health' approach, as well as suggesting means of overcoming the challenges of building cities for the wellbeing of their residents.

\section{Resumen}

El Observatorio de Salud Urbana de Belo Horizonte (OSUBH), establecido en un ambiente académico, fue fundado en 2002, dentro del marco de un vigoroso programa de salud local y nacional. Su misión es fomentar y fortalecer la capacidad de trabajo en investigación en el área de la salud, con la realización de estudios centrados en las poblaciones urbanas, procurando impulsar la planificación para mejorar la salud urbana, especialmente, en las áreas de intensa urbanización asociadas a desigualdades intra-urbanas. La actividad se centra en la adquisición de un conocimiento profundo (métricas) sobre la salud urbana, a través de la investigación científica, con el fin de contribuir a las políticas públicas que pueden interferir en la salud, tanto a nivel individual, como comunitario. En su trayectoria, se han realizado asociaciones y estudios, pero, además, existen muchos desafíos para su legitimación, con el fin de consolidarse como una herramienta para generar información sistemática para gobiernos y poblaciones.

Planificación en Salud; Agenda de Investigación en Salud; Salud Urbana 


\section{Contributors}

M. A. S. Dias, A. A. L. Friche and W. T. Caiaffa contributed to the study design, writing and review of the paper. V. B. Oliveira contributed to the review of the paper.

\section{References}

1. Buss PM, Pellegrini FA. A saúde e seus determinantes sociais. Physis (Rio J.) 2007; 17:77-93.

2. Villar E. Los determinantes sociales de salud e la lucha por la equidad en salud: desafios para el estado y la sociedad civil. Saúde Soc 2007; 16:7-13.

3. Buss PM, Pellegrini FA. Iniqüidades em saúde no Brasil, nossa mais grave doença: comentários sobre o documento de referência e os trabalhos da Comissão Nacional sobre Determinantes Sociais da Saúde. Cad Saúde Pública 2006; 22:2005-8.

4. Teixeira CF, Vilasbôas ALQ. Modelos de atenção à saúde no SUS: transformação, mudança ou conservação? In: Paim JS, Almeida-Filho N, organizadores. Saúde coletiva: teoria e prática. Rio de Janeiro: MedBook; 2014. p. 287-301.

5. Secretaria de Vigilância em Saúde, Ministério da Saúde. Política Nacional de Promoção da Saúde. Brasília: Ministério da Saúde; 2006.

6. Proietti FA, Assunção AA, Rodrigues CS, Oliveira CDL, Andrade ELG, Dias MAS, et al. Observatório de Saúde Urbana de Belo Horizonte. In: Rassi Neto E, Bógus CM, organizadores. Saúde nos aglomerados urbanos: uma visão integrada. Brasília: Organização Pan-Americana da Saúde; 2003. p. 277-96. (Série Técnica Projeto de Desenvolvimento de Sistema e Serviços de Saúde, 3).
7. Caiaffa WT, Ferreira FR, Ferreira AD, Oliveira CL, Camargos VP, Proietti FA. Saúde urbana: "a cidade é uma estranha senhora, que hoje sorri e amanhã te devora". Ciênc Saúde Coletiva 2008; 13:1785-96.

8. Vlahov D, Freudenberg N, Proietti F, Ompad D, Quinn A, Nandi V, et al. Urban as a determinant of health. J Urban Health 2007; 84:154-63.

9. Dias MAS. Promoção à saúde e articulação intersetorial. In: Magalhães HMJ, organizador. Desafios e inovações do SUS em Belo Horizonte: a experiência de 2003 a 2008. Belo Horizonte: Mazza; 2010. p. 63-99.

10. Gomes MA. Orçamento participativo de Belo Horizonte: um instrumento de planejamento da gestão democrática. In: Azevedo S, Barroso R, organizadores. Orçamento participativo: construindo a democracia. Rio de Janeiro: Revan; 2005. p. 49-65.

11. Ministério da Saúde. Relatório final da VIII Conferência Nacional de Saúde. http://conselho.sau de.gov.br/biblioteca/Relatorios/relatorio_8.pdf (accessed on 08/May/2014).

12. Paim JS, Almeida-Filho N. Reforma Sanitária Brasileira em perspectiva e o SUS. In: Paim JS, Almeida-Filho N, organizadores. Saúde coletiva: teoria e prática. Rio de Janeiro: MedBook; 2014. p. 203-9.

13. Brasil. Constituição da República Federativa do Brasil. Brasília: Senado Federal; 1988. 
14. WHO Kobe Centre. Report of Consultation Meeting on Urban Health Metrics Research. http://www. who.int/kobe_centre/publications/urban_health_ metrics_report.pdf (accessed on 08/May/2014).

15. Comissão Nacional sobre Determinantes Sociais da Saúde. As causas sociais das iniquidades em saúde do Brasil. Relatório final, 2008. http://bvsms. saude.gov.br/bvs/publicacoes/causas_sociais_ini quidades.pdf (accessed on 07/May/2014).

16. Comissão para os Determinantes Sociais da Saúde, Organização Mundial da Saúde. Redução das desigualdades no período de uma geração. Relatório final, 2010. http://www.who.int/social_determinants/thecommission/finalreport/en/ accessed on 07/May/2014).

17. WHO Commission on Social Determinants of Health. Knowledge network on urban settings: our cities, our health, our future: acting on social determinants of health equity in urban settings. Geneva: World Health Organization; 2008.

18. Organización Panamericana de la Salud. Segundo Foro Regional de Salud Urbana y Tercer Foro Regional de Promoción de la Salud. Informe final. http://www.cicloviasrecreativas.org/es/salud/ii-foro-regional-de-salud-urbana-ops-oms (accessed on 08/May/2014).

19. Organização Pan-Americana da Saúde. Estratégia e plano de ação sobre a saúde urbana nas Américas. http://www.bvsde.paho.org/texcom/sde/saudeurbana_res.pdf (accessed on 08/May/2014).
20. Organización Mundial de la Salud. 65a Asamblea Mundial de la Salud. Resultados de la Conferencia Mundial sobre los Determinantes Sociales de la Salud. http://apps.who.int/gb/ebwha/pdf_files/ WHA65/A65_R8-sp.pdf (accessed on 07/May/ 2014).

21. Proietti FA, Caiaffa WT. Fórum: o que é saúde urbana? Cad Saúde Pública 2005; 21:940-1.

22. Caiaffa WT, Friche AAL, Dias MAS, Meireles AL, Ignacio CF, Prasad A, et al. Developing a conceptual framework of urban health observatories toward integrating research and evidence into urban policy for health and health equity. J Urban Health 2014; 91:1-16.

23. Nogueira H. Os lugares e a saúde. https://pomba lina.uc.pt/en/livro/os_lugares_e_saúde (accessed on 20/Aug/2014).

24. Diez-Roux AV. Multilevel analysis in public health research. Annu Rev Public Health 2000; 21:171-92.

25. World Health Organization. The WHO Approach to Housing and Health. http://www.euro.who.int/ en/health-topics/environment-and-health/Hous ing-and-health/housing-and-health (accessed on 20/Aug/2014).

Submitted on $07 / \mathrm{Jul} / 2014$

Final version resubmitted on 15/Oct/2014

Approved on 20/Oct/2014 